\title{
AKUNTABILITAS DAN TRANSPARANSI PELAPORAN KEUANGAN MASJID (STUDI EMPIRIS: MASJID JAMI' DI KOTA BANDA ACEH)
}

\author{
Abrar Fauzi Maulana ${ }^{1}$, Ridwan ${ }^{* 2}$ \\ ${ }^{1,2}$ Program Studi Akuntansi Fakultas Ekonomi dan Bisnis Universitas Syiah Kuala \\ e-mail: abrarmaulana1997@gmail.com ${ }^{1}$,ridwan.ibrahim@ unsyiah.ac.id ${ }^{* 2}$
}

\section{* Corresponding Author}

\begin{abstract}
Abstrak
This research is aim to decribe the accountability and transparancy of financial report of the Jami' mosque in Banda Aceh. This research is a describtive-qualitative research. This is a natural research in which the events are not conrolled research. The degree of the interference is a minimal interference. This research apllied cross sectional time horizon. The object of this research is Jami' mosque in Banda Aceh and the subject of this research is the financial manager and BKM division of Jami' mosque. The primary data collected by interview is used in this study. The results of this study indicate in general that the application of accountability and transparancy in the financial reporting of the Jami mosque 'in the city of Banda Aceh has not been implemented.
\end{abstract}

Keywords: Accountability, Transparancy, Mosque, Financial Reporting

\section{Pendahuluan}

Masjid merupakan tempat yang penting bagi umat beragama Islam. Umat Islam tidak hanya menjadikan masjid sebagai tempat beribadah, namun juga menjadikan masjid sebagai tempat menjalankan fungsi pendidikan dan fungsi sosial. Oleh karena itu, masjid dapat didefinisikan sebagai tempat yang multifungsi. Masjid bisa menjadi tempat umat islam untuk melakukan segala aktivitas yang sifatnya positif dan bermanfaat, seperti; aktivitas peribadatan, proses belajar-mengajar ilmu agama atau yang dikenal sekarang Taman Pembelajaran Alquran (TPA), dan dapat digunakan juga sebagai tempat bermusyawarah (Zawawi \& Ramli, 2016).

Dalam menjalankan segala aktivitas masjid termasuk aktivitas operasional, pembangunan/ perenovasian masjid, dan lain-lain, sudah tentu setiap pengurus diharuskan untuk melakukan proses pencatatan untuk mengontrol setiap pendapatan dan juga pengeluaraan yang terjadi. Hal ini dilakukan sebagai wujud pertanggungjawaban kepada pihak- pihak yang menyalurkan, mengifaqkan dananya dalam proses pembangunan/perenovasian masjid. Kemudian pihak pengurus juga diharuskan melakukan pencatatan terhadap aset-aset yang ada di masjid tersebut. Hal ini sama seperti tujuan organisasi publik yang sejenisnya.

Sebagian besar sumber pendanaan pada organisasi keagamaan, umumnya berasal dari umat, namun juga ada yang berasal dari bantuan pinjaman ataupun pihak luar. Seperti yang dikatakan oleh Bastian (2007), organisasi seperti masjid memiliki perolehan dana dalam bentuk infaq, sadaqah, fidyah, dan zakat. Sama halnya dengan sumber dana Masjid di Kota Banda Aceh yang berasal dari publik, yaitu jamaah masjid tersebut dan lainnya. Sumber dana dapat berupa tabungan harian masjid, sumbangan jamaah jumat, sumbangan akad nikah, dan lain-lain. Berikut penerimaan sumbangan tiga bulan terakhir yaitu pada periode Januari-Maret tahun 2019 pada empat Masjid di Kota Banda Aceh:

Tabel 1

Penerimaan dan Pengeluaran Kas Mesjid

\begin{tabular}{|l|l|l|}
\hline \multicolumn{1}{|c|}{ Nama Masjid } & \multicolumn{1}{c|}{ Jumlah Penerimaan } & \multicolumn{1}{c|}{ Jumlah Pengeluaran } \\
\hline Masjid Agung Almakmur & Rp. 1.143.427.500 & Rp.1.567.535.888 \\
\hline Masjid Baitul Musyahadah & Rp. 116.312 .000 & Rp. 120.270 .144 \\
\hline
\end{tabular}




\begin{tabular}{|l|l|l|}
\hline \multicolumn{1}{|c|}{ Nama Masjid } & \multicolumn{1}{c|}{ Jumlah Penerimaan } & \multicolumn{1}{c|}{ Jumlah Pengeluaran } \\
\hline Masjid Darul Falah & Rp. 107.717 .374 & Rp. 56.460 .817 \\
\hline Masjid Jami' Unsyiah & Rp. 117.579 .000 & Rp. 178.149 .000 \\
\hline
\end{tabular}

Sumber: Data observasi awal, 2019

Berdasarkan tabel tersebut diketahui bahwa masjid yang ada di Kota Banda Aceh menerima uang dengan jumlah yang sangat signifikan. Sumbangan dana tersebut harus dikelola oleh masjid sebaik mungkin sebagai pertanggungjawabannya terhadap publik.

Latar belakang dan fenomena penelitian ini terjadi karena peneliti melihat sistem pelaporan laporan keuangan pada masjid hanya dilakukan dengan mengumumkannya didepan jamaah pada kegiatan- kegiatan tertentu, seperti salat jumat, dan hanya beberapa masjid yang mempublikasikannya di papan mading yang dimiliki masjid, pencatatannya juga hanya secara sederhana, yaitu sekedar catatan pemasukan dan pengeluaran.

Sebagai entitas pelaporan akuntansi yang menggunakan dana masyarakat (publik) sebagai sumber keuangannya dalam berbagai bentuk, masjid menjadi bagian dari entitas publik yang semua aktivitasnya harus dipertanggungjawabkan kepada publik, transparansi dan akuntabilitas menjadi kata kunci yang penting bagi entitas publik untuk bertahan dan memaksimalkan perannya pada domain sosial budaya dimana entitas tersebut berada dan berbeda dengan entitas publik lainnya (Simanjuntak, et. al., 2011).

\section{Kerangka Teoritis Mesjid}

Masjid merupakan tempat ibadah juga disebut oleh Bastian dalam Halim dan Kusufi (2014:453) dengan organisasi keagamaan. Secara etimologis, organisasi keagamaan dapat diartikan sebagai organisasi yang fokus gerakannya terkait agama tertentu, yang menyangkut juga permasalahan ibadah atau menjalankan segala kewajiban tuhan terkait agama atau kepercayaan.

\section{Pelaporan}

Pelaporan adalah aspek-aspek yang berhubungan dengan penyampaian dan penyediaan suatu informasi. Aspek yang dimaksud adalah lembaga yang terlibat, seperti entitas pelapor, penyusunan standar, dengan badan pengawas dari organisasi profesi atau pemerintah (Zawawi \& Ramli, 2016).

\section{Pelaporan Keuangan}

Pelaporan keuangan tidak hanya membuat informasi terkait laporan keuangan, tetapi juga memuat cara mengkomunikasikan informasi yang berkaitan, baik secara langsung dan juga secara tidak langsung dengan informasi dari sistem akuntansi.

Pelaporan keuangan diharapkan menginformasikan terkait kinerja keuangan entitas pada satu periode dan bagaimana menejemen dari sebuah entitas tersebut (Mangkona \& Walandouw, 2015).

\section{Akuntabilitas}

"Dalam pandangan Islam akuntabilitas tidak ditujukan hanya kepada masyarakat (stakeholders) sebagai pertanggungjawaban horizontal, namun juga kepada Allah Swt yaitu sebagai pertanggungjawaban vertikal" (Mardiasmo, 2009). Hafidhuddin et al. (2008: 103) mengungkapkan dalam pandangan akuntansi, akuntabilitas merupakan aktivitas atau upaya untuk menghasilkan pengungkapan yang benar dengan proses-proses akuntansi.

Mardiasmo (2004 : 20) menambahkan bahwa akuntabilitas adalah kewajiban pihak pemegang amanah (agent) untuk memberikan pertanggung jawaban, menyajikan, melaporkan, dan mengungkapkan segala aktifitas dan kegiatan yang menjadi tanggung jawabnya kepada pihak pemberi amanah (principal) yang memiliki hak dan kewenangan untuk meminta pertanggung jawaban tersebut. Terdapat dua jenis akuntabilitas:

1. Akuntabilitas vertical (vertical accountability), yaitu pertanggungjawaban atas pengelola keuangan kepada Allah Swt.

2. Akuntabilitas horizontal (horizontal accountability), yaitu suatu pertanggungjawaban pengelola keuangan kepada masyarakat secara luas. 
Tujuan akuntabilitas adalah agar terciptanya kepercayaan publik terhadap pengelolaan keuangan suatu organisasi. Tingginya kepercayaan publik yang ditimbulkan dapat mendorong partisipasi menjadi lebih tinggi pula terhadap pengelolaan manajemen. Lebih utama lagi tujuan akuntabilitas adalah untuk mendorong terciptanya akuntabilitas kinerja suatu organisasi sebagai salah satu syarat untuk terciptanya pengelolaan keuangan yang baik dan terpercaya (Mardiasmo, 2009).

\section{Transparansi}

Nilai transparansi dalam pandangan islam sangat menuntut nilai-nilai kejujuran akan setiap informasi dalam sebuah lembaga organisasi tidak terkecuali organisasi keagamaan seperti halnya masjid. Sehubungan dengan kejujuran, tertulis dalam Q.S. AlIsra' : 35 disebutkan:

Artinya: "Dan sempurnakanlah takaran apabila kamu menakar, dan timbanglah dengan neraca yang benar. Itulah yang lebih utama (bagimu) dan lebih baik akibatnya".

Menurut Mardiasmo (2004) transparansi bermakna keterbukaan suatu organisasi dalam menginformasikan mengenai aktivitas pengelolaan sumberdaya publik kepada para pihak yang membutuhkan informasi. Sutedi (2012 : 11) menambahkan bahwa transparansi adalah penyediaan informasi yang memadai, akurat, dan tepat waktu kepada stakeholder.

Tujuan transparansi adalah menciptakan kepercayaan timbal balik antara suatu organisasi dan masyarakat melalui penyajian informasi dan menjamin kemudahan didalam memperoleh informasi yang akurat dan memadai. Transparansi merujuk kepada prinsip menciptakan lingkungan di mana informasi tentang kondisi, keputusan dan tindakan akan dapat diakses, dilihat, dan dipahami oleh semua partisipan pasar (Abbas \& Zamir, 2008 : 366).

Sutedjo (2009) menyatakan bahwa transparansi dan akuntabilitas merupakan konsep yang berkaitan erat satu dengan yang lain, karena tanpa transparansi tidak mungkin ada akuntabilitas. Sebaliknya transparansi tidak akan banyak bermanfaat tanpa dilengkapi dengan akuntabilitas.

Pembuatan laporan keuangan adalah salah satu bentuk kebutuhan transparansi yang merupakan syarat pendukung adanya akuntabilitas yang berupa keterbukaan (openness) atas aktivitas pengelolaan sumber daya publik. Tujuannya adalah untuk menjelaskan bagaimanakah pertanggungjawaban dilakukan (Mardiasmo, 2009).

\section{Metode Penelitian Desain Penelitian}

Tujuan penelitian ini bertujuan untuk menganalisis apakah pelaporan keuangan Masjid Jami' di Kota Banda Aceh sudah akuntabilitas dan transparansi. Jenis penelitian yang dilakukan dalam penelitian ini adalah menggunakan metode kualitatif deskriptif. Situasi penelitian tidak diatur. Tingkat intervensi dalam penelitian ini adalah intervensi minimal. Horizon waktu yang digunakan adalah cross sectional, yaitu data dikumpulkan sekaligus/satu tahap berupa hasil wawancara dari masing-masing pengurus masjid. Wawancara dilakukan kepada pengurus atau BKM Masjid Jami' di Kota Banda Aceh.

\section{Objek dan Subjek Penelitian}

Objek yang digunakan dalam penelitian ini adalah Masjid Jami' di kota Banda Aceh. Adapun subjek dari penelitian ini adalah bendahara masjid atau Kepala BKM Masjid yang dianggap memiliki pengetahuan atas pengelolaan dan pelaporan di bidang keuangan masjid.

\section{Lokasi Penelitian}

Lokasi penelitian adalah tempat dimana suatu penelitian dilakukan. Dalam penelitian kualitatif penentuan lokasi penelitian merupakan tahap yang sangat penting, karena dapat mempermudah peneliti dalam melakukan penelitian. Lokasi penelitian ini dilakukan di 20 (dua Puluh) Masjid Jami' yang ada di Kota Banda Aceh. Alasan melakukan penelitian pada Masjid Jami' di Kota Banda Aceh karena tipologi masjid jami' merupakan tipologi terbanyak diantara tipologi masjid yang ada di Kota Banda. Dan alasan melakukan penelitian pada 20 masjid adalah untuk mendapatkan perbedaan hasil dari penelitian sebelumnya, dan mencari masjid yang lokasinya terjangkau, karena waktu penelitian ini terbatas dan agar terciptanya hasil yang efektif dan efisien 
Tabel 2.

Daftar Masjid Jami’ yang dijadikan lokasi penelitian yaitu terfokus pada

\begin{tabular}{|c|l|l|}
\hline No. & \multicolumn{1}{|c|}{ Nama Masjid } & \multicolumn{1}{|c|}{ Kecamatan } \\
\hline 1 & Masjid Babul Jannah & Baiturrahman \\
\hline 2 & Masjid Al fitrah & Baiturrahman \\
\hline 3 & Masjid Babunnajah & Meuraxa \\
\hline 4 & Masjid Darul Falah & Syiah Kuala \\
\hline 5 & Masjid An Nur & Syiah Kuala \\
\hline 6 & Masjid Al Mukmin & Syiah Kuala \\
\hline 7 & Masjid Al Muttaqin & Syiah Kuala \\
\hline 8 & Masjid Al Hidayah & Syiah Kuala \\
\hline 9 & Masjid Ar Rahman & Lueng Bata \\
\hline 10 & Masjid Al Hidayah & Lueng Bata \\
\hline 11 & Masjid At Taqwa Muhammadiyah & Kuta Raja \\
\hline 12 & Masjid Ar Rahman & Kuta Raja \\
\hline 13 & Masjid Baitul Musyahadah & Banda Raya \\
\hline 14 & Masjid As Shadaqah & Banda Raya \\
\hline 15 & Masjid Al Ishlahiyah & Ulee Kareng \\
\hline 16 & Masjid Raudhatul Jannah & Ulee Kareng \\
\hline 17 & Masjid Baitul Mukmin & Ulee Kareng \\
\hline 18 & Masjid Al fitrah & Kuta Alam \\
\hline 19 & Masjid Al Abrar & Kuta Alam \\
\hline 20 & Masjid Al Badar & Kuta Alam \\
\hline
\end{tabular}

Sumber: Data diolah, 2019

\section{Sumber Data}

Sumber data pada penelitian ini diperoleh dari Masjid Jami' di Kota Banda Aceh berupa data primer dari hasil wawancara dan data sekunder seperti sumber pustaka, penelitian terdahulu, serta dokumen-dokumen pemberian informan yang berkaitan dengan penelitian ini.

\section{Teknik Pengumpulan Data}

Pengumpulan data dalam penelitian ini dilakukan dengan cara wawancara dan studi dokumentasi

1) Pengumpulan data dengan proses wawancara Dalam penelitian ini jenis wawancara yang akan digunakan adalah wawancara dengan menggunakan kerangka berupa pedoman wawancara. Pedoman wawancara yang digunakan hanya berupa garis besar yang akan ditanyakan agar para informan tidak cenderung mengolah atau mempersiapkan informasi tersebut lebih dulu, serta dapat memberikan penjelasan apa adanya.
2) Pengumpulan data dengan studi dokumentasi Dalam penelitian ini studi dokumenter yang akan digunakan adalah dengan cara mencari data mengenai akuntabilitas dan transaparansi pelaporan keuangan Masjid Jami' di Kota Banda Aceh berupa literatur dan laporan keuangan yang dikeluarkan oleh masing-masing masjid serta dokumen lainnya yang menjadi pendukung dalam penelitian yang diberikan oleh informan.

\section{Teknik Analisis Data}

Peneliti menggunakan Teknik analisis data Teknik berdasarkan yang dikemukakan dalam Bungin (2013:70), yaitu ;

1) Pengumpulan Data

2) Reduksi Data

3) Display data

4) Verifikasi dan Penegasan Kesimpulan 


\section{Hasil Dan Pembahasan}

\section{Struktur Organisasi Masjid}

Layaknya sebuah organisasi, masjid juga memiliki struktur organisasi. Struktur organisasi adalah suatu bagan yang membagi tugas dalam melaksanakan berbagai kegiatan atau melaksanakan tugas yang harus dilaksanakan untuk mencapai tujuan yang yang dirumuskan oleh organisasi.

Struktur kepengurusan masjid sekurangkurangnya terdiri dari :

1) Ketua

2) Wakil Ketua

3) Sekretaris

4) Bendahara

5) Bidang Imarah (Pelaksanaan Ibadah)

6) Bidang Idharah (Administrasi)

7) Bidang Ri'ayah (Sarana dan Prasarana)

8) Bidang Humas/Publikasi

9) Bidang Peringatan Hari Besar Islam (PHBI)

Masing-masing bidang dalam struktur organisasi tersebut dilaksanakan dan diberikan tanggungjawab kepada pengurus sesuai bidangnya. Dimana masing- masing pengurus mengemban tugas dan tanggungjawab selama masa kepengurusannya. Karena itu pengurus atau kepengurusan sebuah masjid sebaiknya mempunyai masa jabatan tertentu, misalnya 2 tahun. 3 tahun, atau selama-lamanya 5 tahun Selain tujuan utama sebagai pelayanan umat, masjid juga memiliki tujuan keuangan untuk mendukung terlaksananya tujuan pelayanan peribadatan. Tujuan keuangan ini merupakan fungsi dan tugas seorang bendahara masjid. Bendahara bertanggungjawab terhadap penerimaan dan pengeluaran kas dan juga dalam pembuatan laporan keuangan masjid.

\section{Akuntabilitas Pelaporan Keuangan Masjid Jami' di Kota Banda Aceh}

Masjid Jami' di Kota Banda Aceh tidak memiliki Standar Operation Procedure (SOP) secara tertulis layaknya sebuah organisasi lain dalam melaksanakan pengelolaan keuangannya. Kendati demikian, pihak pengurus masjid yang bertanggungjawab tetap melaksanakan kewajibannya dengan baik dalam mengelola dan melaporkan keuangan masjid yang sumber dananya berasal dari jamaah (publik). Untuk memastikan kegiatan rutin masjid telaksana dengan lancar, termasuk pelaporan keuangan masjid, maka standar yang diikuti oleh pengurus adalah peraturan- peraturan tahapan pelaksanaan yang sudah menjadi tradisi dalam melaksanakan kegiatan tersebut.

Sebagai bentuk pertanggungjawaban pada dana yang berasal dari Jamaah (publik), Pengurus masjid menerbitkan laporan keuangan atas dana yang telah dikelolanya. Laporan keuangan yang diterbitkan oleh masjid pada umumnya dalam bentuk sederhana dan belum memenuhi standar laporan keuangan organisasi nirlaba, yaitu laporan penerimaan dan pengeluaran kas bentuk pencataan single entry.

Pembuatan laporan keuangan merupakan tanggung jawab bendahara masjid. Dalam pembuatan laporan keuangan, setiap masjid memiliki format tersendiri secara komputerisasi. Umumnya, Laporan keuangan masjid berisikan nomor, tanggal, uraian, penerimaan kas, pengeluaran kas, dan saldo kas. Berikut contoh format laporan keuangan masjid :

Tabel 3

Contoh Format Laporan Keuangan Masjid

\begin{tabular}{|c|l|l|l|l|l|}
\hline No & Tanggal & Uraian & Penerimaan & Pengeluaran & Saldo Kas \\
\hline & & & & & \\
\hline & & & & & \\
\hline & Jumlah & & \\
\hline & Saldo Kas & & \\
\hline
\end{tabular}

Sumber: Data Diolah (2019)

Setiap masjid berkewajiban melaporkan laporan keuangannya pada jamaah selaku pemberi dana dan kepada internal kepengurusan masjid sebagai bentuk tanggungjawab pengurus masjid. Pelaporan kepada jamaah dilakukan dengan cara mempublikasikan kondisi keuangan masjid pada jamaah dalam kurun waktu tertentu, baik berupa laporan keuangan bulanan maupun laporan keuangan mingguan.

Laporan keuangan masjid belum pernah diaudit seacara formal sebagaimana laporan keuangan suatu 
organisasi lain yang diaudit oleh seorang Akuntan Publik. Namun, pengurus masjid mengatakan bahwa kewajaran laporan keuangan yang diterbitkan oleh pengurus bisa secara langsung dinilai oleh jamaah dan internal kepengurusan masjid saat laporan keuangan tersebut dipublikasikan secara transparan.

\section{Transparansi Pelaporan Keuangan Masjid Jami’ di Kota Banda Aceh}

Pengurus masjid mencatat setiap penerimaan dan pengeluaran kas pada buku kas harian masjid secara manual. Kemudian setiap hari jumat, penerimaan dan pengeluaran yang telah dicatat secara manual akan dirangkum dan diketik dengan format yang telah ada untuk membuat laporan keuangan masjid dan akan diumumkan kepada jamaah secara lisan. Laporan ini selanjutnya akan ditempel di sisi kanan dan kiri masjid agar jamaah bisa melihanya.

Setiap hari jumat, pengurus masjid mengumumkan jumlah penerimaan dan pengeluaran yang diperoleh oleh masjid selama kurun waktu

1(satu) minggu dan saldo kas yang dimiliki masjid saat itu. Pengumuman ini dilakukan secara lisan oleh pengurus kepada jamaah sebelum pelaksanaan shalat jumat.

Publikasi kondisi keuangan lainnya yang dilakukan oleh pengurus masjid adalah laporan keuangan mingguan yang ditempel pada papan pengumuman atau dinding masjid. Namun, masih terdapat masjid yang hanya melakukan pengumuman secara lisan tanpa mempublikasikan laporan keuangan yang mana laporan keuangan hanya diperuntukkan sebagai arsip kepengurusan masjid.

Masjid tidak memiliki sarana khusus untuk penyampaian saran dan kritik dari jamaah. Jika jamaah ingin menyampaikan saran atau kritik, maka jamaah bisa menyampaikan secara langsung secara lisan kepada pengurus. Pengurus masjid bisa memberikan tanggapan secara langsung atau mendiskusikan saran dan kritik tersebut bersama dengan pengurus lainnya. Kritik dan saran akan dipertimbangkan oleh pengurus, apabila sesuai maka akan diterima. Selain secara lisan, terdapat juga jamaah yang memberikan saran dan kritik secara tulisan melalui kotak tabungan amal.

\section{Kesimpulan, Keterbatasan dan Saran Kesimpulan}

1) Masjid Jami' di Kota Banda Aceh belum sepenuhnya menerapkan akuntabilitas dalam pelaporan keuangannya, walaupun tidak memiliki SOP tertulis, namun dalam pelaksanaan kegiatan, pengurus mengikuti aturan-aturan yang sudah menjadi tradisi dalam kepengurusan masjid. Pengurus membuat laporan keuangan masjid berupa laporan penerimaan dan pengeluaran kas dalam bentuk single entry yang diserahkan oleh pengurus kepada jamaah dan internal kepengurusan, serta beberapa pihak tertentu lainnya. laporan keuangan masjid tidak diaudit oleh akuntan publik, namun kewajaran laporan bisa dinilai oleh jamaah secara langsung.

2) Pelaporan keuangan masjid sudah transparan dengan dapat diaksesnya laporan keuangan masjid oleh jamaah melalui publikasi dan media yang dilakukan dan disediakan oleh pengurus, pengurus juga menerima saran dan kritik dari jamaah.

\section{Keterbatasan}

Penelitian ini hanya dilakukan pada 20 (dua puluh) Masjid di Kota Banda yang dipilih secara random, dalam hal ini penulis sangat menyadari bahwa penelitian ini memiliki begitu banyak kekurangan dan kelemahan dikarenakan banyaknya masjid yang harus diwawancarai dan kurangnya data yang diperlukan.

\section{Saran}

Untuk memahami dan menelaah penelitian selanjutnya ada beberapa saran yang dapat ditemukan.

a) Saran Akademik

Agar peneliti selanjutnya dapat meneliti tentang mengapa pengurus masjid enggan untuk membuat laporan keuangannya secara akuntabilitas dan transparansi.

b) Saran Praktis

1) Bagi pemerintah, ada baiknya melakukan audit terhadap laporan keuangan masjid.

2) Bagi pihak pengurus masjid, ada baiknya membuat laporan keuangan yang memenuhi standar, membuat website untuk publikasi

\section{Daftar Pustaka}

Abbas, Mirakhor \& Zamir Iqbal. 2008. Pengantar Keuangan Islam Teori dan Praktik. Jakarta: Kencana.

Abdussalam, H.R. 2009. Hukum Kepolisian Sebagai 
Hukum Positif dalam Disiplin Hukum. Jakarta: Restu Agung.

Adnan \& Akhyar M.2012. The Financial Management Practices of The Mosques in the Special Region of Yogyakarta Province, Indonesia. Tazkia Islamic Finance and Business Review Volume 8.2

Antonio, M.S. 2002. Bank Syariah dan Teori ke Praktek. Jakarta: Gema Insani

Arifuddin, M., Safaruddin, \& Falziah. 2017. Persepsi

$\begin{array}{lcr}\text { Pengelolaan } & \text { Keuangan Desa } & \text { Dalam } \\ \text { Mewujudkan } & \text { Transparansi } & \text { dan }\end{array}$

Akuntablitas

Keuangan desa di Kecamatan Mawasangka Kabupaten Buton Tengah. Jurnal Akuntansi Dan Keuangan, II, 23-38.

Aryani. 2007. Prinsip dan Akuntabilitas dalam Tata Kelola Perusahaan Daerah Air Minum Kota Salatiga. Skripsi tidak dipublikasikan. Salatiga: Universitas Kristen Satya Wacana

Asdar, U., Ludigdo, \& Widya. Y. 2014. Phenomonological Study of Financial Accountability of Mosque. IOSR Journal of Economic and Finance (IOSR-JEF) volume 5 issue 4.

Basri, H., Afifudddin \& Siti. N. 2010. Towards Good Accountability : The Role of Accounting in Islamic Religious Organizations. World Academy of Science, Engineering, and Technologi 66

Bastian, I. 2007. Akuntansi untuk LSM dan Partai Politik. Jakarta: Erlangga.

2007. Akuntansi Yayasan dan Lembaga Publik. Jakarta: Erlangga.

Bungin, B. 2013. Metodologi Penelitian Sosial dan Ekonomi. Jakarta: Kencana Prenada Media Group.

Damayanti, A. 2013. Analisis Transparansi dan Akuntabilitas Pengelolaan Keuangan Masjid Kampus. Skripsi. Bandung: Universitas Pendidikan Indonesia.

Hafidhuddin, D. 2008. The Power of Zakat Studi Perbandingan Pengelolaan Zakat Asia Tenggara. Universitas Islam Negri Malang Bekerjasama dengan Pusat Kajian Zakat dan Wakaf "El-Zawa"

Halim, A, \& Kusufi.S. 2013. Akuntansi Sektor Publik. Jakarta: Salemba Empat.
Hanafi, R. 2015. Akuntabilitas dan Pengelolaan Keuangan di Masjid melalui pendekatan Fenomologi. Skripsi. Surakarta: Universitas Muhammadiyah.

Hartatik, I. P. 2014. Buku Pintar Membuat SOP (Standar Operasional Prosedur). Yogyakarta: Flashbooks.ha

Ikatan Akuntan Indonesia. 2018. Pernyataan Standar Akuntansi Keuangan Nomor 1 tentang Penyajian Laporan Keuangan.

------. 2018. Pernyataan Standar Akuntansi Keuangan Nomor 45 tentang Laporan Keuangan Entitas Nirlaba.

Ihsan, H \& Gustina. 2008. Manajemen dan Akuntabilitas Institusi Pengelola Zakat. Jurnal Akuntansi \& Manajemen Vol. 3 no. 1 Juni 2008. Kemenag RI., http://simas.kemenag.go.id//Jumlah Masjid di Banda Aceh,

Khairaturrahmi. 2017. Akuntabilitas dan Transparansi Pengelolaan Keuangan Masjid di Kota Banda Aceh. Skripsi. Banda Aceh: Universitas Syiah Kuala.

Kristianten. 2006. Transparansi Anggaran Pemerintah. Jakarta: Bineka Cipta.

Mahmudi. 2007. Manajemen Kinerja Sektor Publik. Yogyakarta: Unit Penerbit dan Percetakan Sekolah Tinggi Ilmu Manajemen YKPN.

Mangkona, S. W. S., \& Walandouw, S. K. 2015. The Application of the Sfas No . 45 on Financial Reporting in the Non- Profit Organization Nurul Huda Mosque Kawangkoan. EMBA, 3(ISSN 2303-1174), 304-314.

Mardiasmo. 2004. Perwujudan transparansi dan akuntabilitas publik melalui ASP : suatu saran good governance. Jurnal Akuntansi Pemerintah. Vo; 2 no 1 mei 1-17.

Moleong, L. J. 2016. Metodologi Penelitian Kualitatif Edisi Revisi. Bandung: PT. Remaja Rosdakarya. Moleong. 2009. Akuntansi Sektor Publik. Yogyakarta: ANDI.

Nazila. S.R. 2018. Analisis Penerapan Laporan Keuangan Entitas Nirlaba Berdasarkan PSAK No. 45 pada Masjid di Banda Aceh. Skripsi. Banda Aceh: Universitas Syiah Kuala.

Nurjannah. 2018. Akuntabilitas Pengelolaan 
Keuangan Masjid: PSAK No. 45 Tentang Pelaporan Keuangan Organisasi Nirlaba (Sudi Pada Masjid Al-Markaz Al-Islami Jendeeral M.Jusuf). Skripsi. Makassar: Universitas Islam Negeri Alauddin Makassar.

Nurlailah, Nurleni, \& Madris. 2014. Akuntabilitas Keuangan Masjid di Kecamatan Tubo Sendana Kabupaten Majene, 4, 206-217.

Peraturan Kepala Badan Kepegawaian Negara Nomor 35 Tahun 2014 tentang Perubahan atas Peraturan Kepala Badan Kepegawaian Negara Nomor 1

Tahun 2009 tentang Pedoman Penyelenggaraan Pendidikan dan Pelatihan Analisis Kepegawaian.

Peraturan Menteri Dalam Negeri Republik Indonesia Nomor 38 Tahun 2018 tentang Pedoman Penyusunan Anggaran Pendapatan dan Belanja. Pontoh, C. R. 2013 Penerapan Laporan Keuangan Organisasi Nirlaba Berdasarkan PSAK No. 45 Pada Gereja BZL. EMBA, 1(45), 129-139.

Pratama, M. A. 2017. Analisis Penerapan Prinsip Akuntansi Terhadap Akuntabilitas Laporan Keuangan Masjid (Studi Kasus 5 Masjid Di Medan), 96.

Rahayu, R. A. 2014. Tranparansi dan Akuntabilitas Pelaporan Keuangan Masjid Agung Al-Akbar Surabaya. Jurnal Review Akuntansi Dan Keuangan, 4(2), 631-638.

Sailendra, Y. 2015. Langkah-Langkah Praktis Membuat SOP. Yogyakarta : Trans Idea Publising

Sanusi, A. 2014. Metodologi Penelitian Bisnis. Jakarta: Salemba Empat.

Sekaran, U \& Bougie R.. 2017. Metode Penelitian Untuk Bisnis. Edisi Keenam, Buku Satu. Jakarta: Salemba Empat.

Shalihin, D. 2007. Good Governance di Sektor Publik untuk Meningkatkan Akuntabilitas Kinerja Lembaga Publik

Simanjuntak, D. A \& Januarsi. Y. Simposium Nasional Akuntansi xiv aceh 2011. Akuntabilitas dan Penelolaan Keuangan Masjid.

Siskawati, E. 2016. Bagaimana Masjid dan Masyarakat Saling Memakmurkan? Pemaknaan Akuntabilitas Masjid. Jurnal Akuntansi
Multiparadigma Volume 7 Nomor 1.

Sugiyono. 2017. Metode Penelitian Kuantitatif, Kualitatif dan $R \& D$. Bandung: Alfabeta.

Sukrisno, A. 2012.Auditing Petunjuk Praktis Pemeriksaan Akuntan Oleh Akuntan Publik.

Jilid 1, Edisi Keempat. Jakarta : Salemba Empat. Sutedi, A. 2012. Good Corporate Governance. Jakarta: Sinar Grafika.

Sutedjo. 2009. Persepsi Stakeholders terhadap Transparansi dan Akuntabilitas Pengelolaan Keuangan Sekolah. Tesis. Semarang: Universitas Diponegoro.

Zawawi, M \& Noriah. R. 2016. Pencatatan Keuangan Masjid yang ada di Kota Pontianak. Jurnal Audit Dan Akuntansi Fakultas Ekonomi Dan Bisnis. 5(May), 31-48. 